2

IN SAN

\title{
Proses Pengambilan Keputusan Menjadi LGBT pada Individu dengan Karakteristik Religius
}

\author{
HELSA EVANIA PRASTOWO, NASTITI DWICAHYANI, GITAJIWA SEKARNUSA GANIES, PUTRI \\ ANINDITA VINASTHIKA, \& NAFIA KUSUMA INDRAYATI* \\ Magister Profesi Psikologi, Fakultas Psikologi Universitas Airlangga
}

\begin{abstract}
ABSTRAK
Penelitian ini bertujuan untuk meperoleh gambaran proses pengambilan keputusan menjadi LGBT pada individu yang religius. Pendekatan yang digunakan adalah kualitatif fenomenologi. Penelitian dilakukan di Surabaya dengan satu informan lesbian dengan karakteristik religius. Data dalam penelitian menggunakan wawancara semi terstruktur. Metode analisis data menggunakan analisis Interpretative Phenomenological Analysis (IPA). Hasil penelitian menunjukkan bahwa partisipan. Hasil penelitian menunjukkan bahwa individu dengan karakteristik religius mengambil keputusan menjadi lesbian melalui beberapa tahapan yaitu menilai tantangan, mensurvei alternatif, mempertimbangkan alternatif, menyatakan komitmen, bertahan terhadap feedback negatif. Faktor yang berperan dalam pengambilan keputusan terdiri dari faktor internal berupa religiusitas partisipan yang memberi pertimbangan terkait pengambilan keputusan, serta faktor eksternal berupa dukungan sosial dari pasangan, teman dekat, keluarga dan ketiadaan penolakan secara langsung dari lingkungan sekitar. Dimensi religiusitas yang dimiliki pada partisipan adalah dimensi intelektual, dimensi ideologi, dimensi ritualistik, dimensi perasaan dan dimensi konsekuensial.
\end{abstract}

Kata kunci: LGBT, religius, pengambilan keputusan

\begin{abstract}
This study aimed to find out the decision-making process of religious lesbian individual. The approach used was qualitative phenomenology. The study was conducted in Surabaya with one lesbian informant, who was identified as a religious person. The data were collected with semistructured interview. The method of data analysis was Interpretative Phenomenological Analysis (IPA). The results showed that the individual, who was identified as religious person, decided to be a lesbian through stages of decision making. The stages were assessing challenges, surveying alternatives, considering alternatives, expressing commitment, and surviving negative feedback. Factors that played a role in the decision making were internal factor, participant's religiosity affected the the decision making, and external factor, social support from partners, close friends, family and the acceptance from her circle. The dimensions of religiosity of the participant were intellectual dimensions, ideological dimensions, ritualistic dimensions, feelings dimensions, and consequential dimensions.
\end{abstract}

Keywords: LGBT, religiosity, decision making 
INSAN Jurnal Psikologi dan Kesehatan Mental, 2019, Vol. 4(1), 43-53, doi: 10.20473/jpkm.v4i12019.43-53 Dikirimkan: 16 Oktober 2019 Diterima: 10 Desember 2019 Diterbitkan: 27 Februari 2020

Editor: Rizqy Amelia Zein

*Alamat korespondensi: Fakultas Psikologi Universitas Airlangga, Jalan Airlangga 4-6 Surabaya 60286. Posel: nafiakusuma95@gmail.com

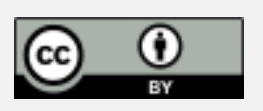

Naskah ini merupakan naskah dengan akses terbuka dibawah ketentuan the Creative Common Attribution License (http://creativecommons.org/licenses/by/4.0), sehingga penggunaan, distribusi, reproduksi dalam media apapun atas artikel ini tidak dibatasi, selama sumber aslinya disitir dengan baik.

\section{PENDAHULUAN}

Isu terkait Lesbian Gay Bisexual Transgender (LGBT) merupakan topik yang menarik untuk didiskusikan dan ditelaah oleh para ahli di Indonesia. Seperti fenomena yang semakin marak terjadi di Jawa Timur, yakni penggerebekan pesta gay oleh polisi beberapa waktu lalu di Surabaya (Pasopati, 2017). Selain itu, terdapat kasus yang terjadi di Surabaya timur yakni, mahasiswa gay melakukan pelecehan terhadap empat anak laki-laki di bawah umur (Romadoni, 2018). Peristiwa-peristiwa tersebut menuai keprihatinan dan perdebatan.

Sebagai kelompok minoritas, keberadaan mereka dianggap sebagai perilaku menyimpang dan membawa masalah sosial. Majelis Ulama Indonesia (MUI) memfatwakan bahwa LGBT adalah haram. Fatwa MUI tersebut dituangkan dalam Nomor 57 Tahun 2014 mengenai Lesbian, Gay, Sodomi, dan Pencabulan. Kemudian, Ermayani (2017) menyatakan bahwa LGBT dianggap bertentangan dengan Pancasila dan Undang-Undang Dasar 1945 khususnya pasal 29 ayat 1 dan Pasal 28. Lebih lanjut, LGBT juga dianggap bertentangan dengan Undang-Undang Nomor 1 Tahun 1974 tentang perkawinan. Undang-Undang tersebut menjelaskan bahwa perilaku seksual hanya diwadahi perkawinan yang merupakan ikatan lahir batin antara pria dan wanita sebagai suami istri yang bertujuan membentuk keluarga berdasarkan Ketuhanan Yang Maha Esa.

Meskipun mendapat tentangan dan penolakan dari berbagai pihak, gaya hidup kaum LGBT dewasa ini semakin marak dan semakin mendapat sorotan dari masyarakat terutama kejadian pesta seks yang belakangan sering terungkap di media. Moammar Emka dikutip dari Jawa Pos (2017) menyatakan bahwa pesta semacam itu semakin populer setelah tahun 2012 ke atas. Jumlah kaum gay terus bertambah. Di tahun 2012, terdapat 1 juta orang dan hal ini diprediksi naik sebesar 3 persen dari penduduk Indonesia ungkap Moammar Emka yang mengutip dari Kemenkes.

Peningkatan jumlah LGBT diikuti dengan keberagaman karakteristik pelakunya yang tidak selalu berkonotasi negatif namun juga terdapat individu LGBT yang melekatkan agama pada dirinya. Terdapat pernikahan gay muslim di London. Mereka meyakini bahwa setiap orang berhak menjadi gay dan seorang muslim. Di Indonesia, terdapat Pesantren waria Al-Fatah yang bertempat di Yogyakarta. Pesantren tersebut merupakan salah satu bukti perjuangan kelompok LGBT yang memiliki kesadaran bahwa kaum waria memerlukan tempat untuk beribadah karena pada hakikatnya waria juga memiliki hak yang sama di hadapan Tuhan (Mu'tamiroh, 2018).

Agama dan doktrin agama menentukan norma-norma sosial mengenai apa pola keintiman seksual seperti apa yang dapat diterima, sistem ideologis ini juga menentukan siapa yang merupakan pasangan seksual yang sesuai, dan menggarisbawahi konsekuensi dari pelanggaran terhadap kebiasaan seksual yang tidak sesuai dan akan memberikan sanksi agama atau sanksi sosial (Halkitis et al., 2009). 
Beberapa individu LGBT memutuskan untuk memiliki pola hubungan intim dengan memilih pasangan dan identitas seksual yang bertentangan dengan norma-norma konvensional. Keinginan mereka untuk mengintegrasikan agama, spiritualitas, dan seksualitas sering diwarnai konflik (Greenberg \& Bystrn, 1982; Goodwill, 2000; Shuck \& Liddle, 2001; Rodriguez \& Oullette, 2000; Sullivan-Blum, 2004). Meski demikian, ada beberapa pengakuan dari individu dengan karakteristik religius namun mengambil keputusan untuk menjadi LGBT. Baginya, agama dan orientasi seksualnya dapat berjalan beriringan tanpa menimbulkan dilema atau konflik batin.

"Menurutku agama sama orientasiku seksualku ga ada masalah. Agama itu pedoman hidup, tapi kita ga bole ngilangin nilai-nilai kemanusiaan. Aku yakin Allah juga mencintai hamba-hambanya yang menurut manusia itu sendiri adalah aib, kadang manusia sendiri yang menuhankan dirinya sendiri" (F, wawancara, 11 November 2018).

Berbeda dengan ML, ia mengalami tekanan dari lingkungannya atas statusnya sebagai seorang muslim dan memiliki orientasi seksual menyimpang. Di bawah tekanan tersebut, ia menjalani hidupnya sebagai seorang muslim.

"Ketika saya berada di kondisi terburuk, saya meminta Allah (SWT) untuk membuat saya tetap hidup. Saya belajar banyak tentang islam, memang aman tapi membuat stress. Mengkhawatirkan jika ada orang yang tahu, menjalani risiko dipecat, dan terusmenerus meyakinkan bahwa diri saya 'cukup normal' ini melelahkan" (ML, artikel diakses, 11 November 2018).

Sedangkan RB menyatakan bahwa ia awalnya adalah seorang LGBT namun sekarang telah mengubah jalan hidupnya seperti semula setelah mendekatkan diri pada Tuhan.

"Waktu sholat gue bener-bener ngerasa enteng banget ya diri gue. Nah, dari situlah gue akhirnya pelan-pelan nih. Kayak, oh akhirnya gue sholat, masih bolong-bolong. Akhirya setiap sholat gue ngerasa ganjel, gaenak kaya gini, dan lama-lama gue memutuskan kembali jadi RB" (RB, Youtube diakses 11 November 2018).

Kutipan pernyataan F, ML dan RB di atas membuktikan bahwa adanya perbedaan konflik dan pertimbangan dalam mengambil keputusan untuk menjadi LGBT pada individu yang memiliki karakteristik religius. Konflik tersebut dapat berupa konflik intrapersonal dan konflik interpersonal. Konflik intrapersonal terjadi di dalam individu dan masing-masing orang yang mengalami konflik memiliki perjalanan uniknya tersendiri. Di sisi lain, konflik interpersonal merupakan konflik yang melibatkan significant others di sekitar mereka seperti keluarga, teman-teman, atau komunitas agama (Subhi, dkk., 2015). F tidak mengalami konflik intrapersonal maupun interpersonal karena memaknai religiusitas dan orientasi seksual sebagai dua hal yang berdiri sendiri. Berbeda dengan ML, ia mengalami konflik interpersonal karena tekanan yang ia dapatkan berasal dari lingkungan yang mana menimbulkan konflik pada dirinya. Meski demikian, ia tetap memegang Islam sebagai agamanya. RB yang awalnya adalah seorang LGBT menemukan jalan untuk kembali ke jati dirinya yang semula setelah menjalankan salat. Dapat dikatakan bahwa ia mengalami konflik intrapersonal karena dilema yang ia alami sendiri tanpa ada keterlibatan orang lain. Dapat dikatakan bahwa gangguan yang muncul dari konflik internal merupakan elemen penting dalam pengembangan sistem yang kompleks seperti manusia (Mahoney, 2002); gangguan tersebut dapat menyebabkan hasil yang bersifat negatif maupun positif bagi individu.

Melihat fenomena ini, religiusitas yang seharusnya menjadi bentuk kontrol diri seorang individu dan menjadi indikator bahwa dirinya memiliki kesehatan mental. Namun kenyataannya, masih terdapat individu yang memiliki keyakinan agama namun juga menjalani hidup sebagai LGBT. Perilaku dan keyakinan pada agama juga telah diidentifikasi sebagai sebuah komponen penting untuk mengatasi

INSAN Jurnal Psikologi dan Kesehatan Mental 2019, Vol. 4(1), 43-53

doi: 10.20473/jpkm.v4i12019.43-53 
masalah yang bersifat negatif yang tejadi didalam kehidupan seorang gay dan gangguan seks lainnya, keyakinan pada konsep religiusitas dapat meningkatkan kepercayaan diri, mengurangi stress, meningkatkan fungsi kognitif pada konsep diri seseorang dan penerimaan diri yang lebih baik (Pargament et al., 2004; Park, 2006 dalam Sarit et al., 2010). Kemudian terdapat literatur yang menghubungkan agama dan spiritualitas dengan kesehatan fisik (George, Ellison \& Larson, 2002; Koenig, McCullough \& Larson, 2001; Larson, Swyers \& McCullough, 1998; Seybold \& Hill, 2001; Thoresen, 1999; Thoresen, Harris \& Oman, 2001; Powell, Shahabi \& Thoresen, 2003) dan kesehatan mental (Larson et al., 1998; Plante \& Sherman, 2001).

Meskipun menyalahi nilai-nilai agama yang mereka anut dan mendapatkan penolakan dari masyarakat, individu dengan karakteristik religius tetap mengambil keputusan untuk menjadi LGBT. Hal ini menarik perhatian peneliti untuk meninjau secara fenomenologi mengenai pengambilan keputusan untuk menjadi LGBT pada individu yang memiliki karakteristik religius. Peneliti berusaha memahami lebih dalam mengenai pengalaman individu dengan karakteristik religius dalam mengambil keputusan untuk menjadi LGBT.

\section{LGBT (Lesbian, Gay, Bisexsual, Transgender)}

Berdasarkan Kamus Lengkap Psikologi (Chaplin, 2001), “Lesbian yaitu homoseksualitas di kalangan wanita. Gay yaitu homoseksualitas di kalangan pria. Biseksual yaitu keadaan merasa tertarik sama kuatnya pada kedua jenis kelamin, perempuan maupun laki-laki". Hubungan sesama jenis atau biasa disebut dengan homoseksual merupakan aktivitas seksual yang memilih pasangan seksual dari sesama jenis (Demartoto, 2010). Dalam hubungan ini, pasangan terlibat dalam emosi, romantik serta seksual dengan sesama jenis. Dengan kata lain hubungan sesama jenis adalah ketika laki-laki memiliki pasangan laki laki atau yang biasa disebut Gay, dan perempuan yang memiliki pasangan perempuan atau yang biasa disebut Lesbian. Homoseksualitas dapat mengacu pada orientasi seksual yang ditandai dengan terlibatnya seseorang secara emosi dengan individu yang memiliki jenis kelamin sama secara biologis atau identitas gender yang sama.

Hawkin (dalam Kaplan, 1997) menyatakan bahwa istilah "gay" dan "lesbian" termasuk dalam kombinasi identitas diri dan identitas sosial. Dalam diri individu dapat timbul suatu perasaan ketika bergabung dalam kelompok sosial yang memiliki label sama. Studi yang dilakukan Parlindungan dan Brilianty (2014) menunjukkan bahwa komunitas Gay di kota Padang rutin berkumpul untuk mengkaji masalah keagamaan, seperti mengadakan pengajian, pembelajaran Alquran, dan pembahasan agama lainnya. Hasil penelitian tersebut juga menyatakan bahwa keseluruhan partisipan Gay masih menjalankan dan mengamalkan agama Islam dengan baik, namun mereka tidak bisa melepaskan kenyataan diri sebagai seorang Gay. Studi yang dilakukan Muiz (2017) menunjukkan bahwa lesbianism itu tercipta dari relasi pemikiran mereka sendiri. Beberapa lesbian ada yang lahir dan dididik dalam dunia pendidikan Islami seperti pesantren atau kampus Islam.

\section{Pengambilan Keputusan}

Pengambilan keputusan menurut Janis \& Mann (1979) adalah suatu proses pemilihan terhadap alternatif yang dianggap terbaik oleh individu. Proses tersebut meliputi tahapan-tahapan yang harus dilalui oleh individu. Pada setiap tahapan tersebut individu dihadapkan pada alternatif yang harus dipilih dalam mencapai tujuan yang diharapkan. Janis dan Mann (1977) menyatakan sebuah model terdapat lima tahap dalam pengambilan keputusan. Lima tahapan tersebut yaitu:

(1) Menilai tantangan

INSAN Jurnal Psikologi dan Kesehatan Mental 2019, Vol. 4(1), 43-53

doi: $10.20473 /$ jpkm.v4i12019.43-53 
Ketika individu menerima informasi yang kurang jelas, ia akan mengalami konflik sementara dan meragukan apa yang ia percayai selama ini. Jika pada tahap pertama ini individu sukses menghadapi suatu tantangan, maka ia akan lebih siap menghadapi temuan baru untuk melakukan tindakan yang diinginkan.

(2) Survei Alternatif

Pada tahap ini individu yang merasa terguncang oleh informasi baru akan mulai mencari alternatif lain dari berbagai pilihan yang ada. Ia meminta saran dan informasi dari pihak lain serta alternatif tindakan dari yang diinginkan. Keputusan individu sebagian besar mengarah pada keputusan awal, namun ia mulai mencari informasi baru dan alternatif yang lebih baik.

(3) Mempertimbangkan alternatif

Individu melakukan analisis dan evaluasi dari sisi positif dan negatif dari setiap alternatif sampai merasa yakin untuk memilih sesuai tujannya. Muncul keraguan individu yang tidak lagi merasa puas dengan tindakan sebelumnya namun belum berkomitmen pada alternatif baru. Ia terbuka dengan informasi baru sampai menemukan keyakinan bahwa hal tersebut adalah pilihan yang terbaik.

(4) Menyatakan Komitmen

Saat individu telah memutuskan secara internal akan melakukan suatu tindakan baru, ia secara berhati-hati akan mengungkapkan keputusan tersebut kepada orang lain.

(5) Bertahan melalui feedback negatif

Keputusan yang diambil tanpa keraguan, pada awalnya akan memberikan kenyamanan dan kesenangan. Namun tidak jarang akan muncul ketidaksukaan atau feedback negatif dari orang lain. Individu akan bertahan dalam menghadapi masalah ini. Ketika sampai titik dimana ia tidak mampu bertahan, ia akan kembali ke 3 tahap sebelumnya dan mencari alternatif-alternatif lain yang lebih baik.

\section{Religiusitas}

Religiusitas merupakan suatu tingkat keberagamaan pada diri seseorang. Individu yang dikatakan memiliki religiusitas tinggi adalah individu yang mampu mensinergikan perilakunya di dunia sesuai dengan ajaran agama yang dianutnya (Subandi, 2013). Faktor-faktor yang memengaruhi religiusitas seseorang yaitu faktor sosial, pengalaman pribadi, perasaan akan kebutuhan, dan intelektual (Thouless, 2000). Penelitian Wulansari (2014) di Bandung menyatakan adanya dinamika dimensi religiusitas yang berbeda pada ketiga partisipan Lesbian. Ketiga partisipan memiliki kesamaan dalam dimensi religiusitas yaitu dimensi penghayatan (the experiential dimensions / religious feeling), dan Dimensi Pengamalan atau Konsekuensi (the consequential dimensions / religious effect), mereka mengalami perasaan bersalah dengan keputusannya untuk menjadi seorang lesbian namun, tetap memilih untuk menjalani kehidupan sebagai seorang lesbian meskipun tidak secara "terbuka". Perbedaan dari ketiga subyek adalah dalam Dimensi Praktik Agama (the ritualistic dimensions/religious practices). Mereka memiliki intensitas perilaku beribadah yang beragam.

Tokoh yang berpengaruh dalam mendefinisikan religiusitas adalah Glock \& Stark (1965). Menurut Glock \& Stark, religiusitas dipandang sebagai komitmen religius yang dimiliki oleh individu, terkait agama dan keyakinan, dan terlihat dari perilaku individu tersebut dalam melaksanakan ritual agama dan keyakinan iman yang dianut. Glock dan Stark (1968) menjelaskan bahwa religiusitas memiliki 5 dimensi yaitu:

(1) Dimensi Intelektual

INSAN Jurnal Psikologi dan Kesehatan Mental 2019, Vol. 4(1), 43-53

doi: $10.20473 /$ jpkm.v4i12019.43-53 
Dimensi ini merujuk pada ekspektasi sosial bahwa orang yang religius memiliki pengetahuan tentang agamanya dan mereka dapat menjelaskan pandangannya terkait dengan agama itu sendiri. Indikator umum untuk dimensi ini adalah frekuensi berpikir tentang masalah-masalah agama.

(2) Dimensi Ideologi

Dimensi ini merujuk pada ekspektasi sosial bahwa individu yang religius memiliki kepercayaan terkait eksistensi dan esensi dari kenyataan transendental dan relasi antara transenden dan manusia. Dimensi ini terkait sejauh mana individu menerima dogma agamanya dan mempercayainya.

(3) Dimensi Ritualistik

Dimensi ini merujuk pada tingkatan individu melakukan kewajiban-kewajiban ritual agamanya. Dimensi ini terdiri dari dua yaitu pelaksanaan di publik dan pelaksaan saat sendiri. Pelaksaan publik merujuk pada ekspektasi sosial dimana individu yang religius memiliki partisipasi dalam kegiatan komunitas keagamaan. Manifestasinya dapat dilihat dari partisipasi dalam ritual dan aktivitas komunal. Indikator dimensi ini terkait dengan frekuensi seseorang dalam menjadi bagian dari pelayanan keagamaan. Sementara pelaksanaan ritual saat sendiri, individu yang religius akan mengabdikan diri pada transendensi dalam aktivitas dan ritual individu di ruang privat.

(4) Dimensi Perasaan

Dimensi perasaan atau dimensi pengalaman merujuk pada pengalaman-pengalaman individu yang ia anggap melakukan komunikasi dengan Tuhan. Suatu hal yang terjadi dipercayai oleh individu merupakan tanda dari Yang Di Atas. Pengalaman baik maupun buruk dipercayai terjadi atas kuasa Tuhan, dan pengalaman ini memengaruhi individu secara emosional.

(5) Dimensi Konsekuensial

Dimensi konsekuensial menyatakan bahwa individu yang religius menunjukkan perilaku yang konsekuen dengan ajaran agamanya. Dimensi ini melihat sejauh mana individu melakukan hal sesuai dengan perintah agamanya dan menjadikan agama sebagai pedoman dalam melakukan tindakan sehari-hari.

Pandangan Glock \& Stark menggunakan pendekatan sosiologi. Tetapi lima inti dimensi ini juga mengulas dari sudut pandang psikologis dilihat dari representasi konten religius. Dimensi intelektual dan ideologi mengacu pada pikiran, dimensi ritualistik mengacu pada tindakan, dan dimensi perasaan atau pengalaman mengacu pada pengalaman, emosi dan persepsi.

\section{METODE}

\section{Desain Penelitian}

Penelitian ini merupakan penelitian kualitatif dengan pendekatan penelitian fenomenologi. Pendekatan fenomenologi merupakan pendekatan penelitian yang menekankan pada kesadaran dari sudut pandang informan dengan melihat pada pengalaman subjektif yang muncul pertama kali pada diri informan (Husserl dalam Moloeng, 2010). Pendekatan fenomenologi dalam penelitian kualitatif bertujuan untuk menggambarkan arti dari suatu pengalaman yang pernah dialami oleh seseorang terkait suatu hal (Herdiansyah, 2015). Penilitian dengan menggunakan pendekatan fenomenologi menekankan aspek subjektif dari informan atau partisipan, dimana peneliti berusaha masuk dalam kehidupan konseptual seseorang hingga menemukan dan memahami fenomena apa dan bagaimana yang terjadi dalam kehidupan partisipan (Moleong, 2010). Dalam fenomologi, peneliti harus mampu untuk memahami arti sebuah peristiwa dan kejadian atau fenomena yang terjadi dalam kehidupan seseorang yang dijadikan partisipan penelitian, serta mampu melihat bagaimana kejadian, peristiwa, serta fenomena tersebut berhubungan dan mempengaruhinya dalam situasi tertentu. 


\section{Unit Analisis Penelitian}

Fokus penelitian ini adalah untuk mengkaji dan menganalisis beberapa hal terkait same sex relationship dengan khusus melihat pada hubungan sesama jenis antara wanita dengan wanita (lesbian), religiusitas dan perannya dalam pengambilan keputusan, serta proses atau tahapan pengambilan keputusan itu sendiri.

\section{Partisipan Penelitian}

Penentuan partisipan pada penelitian ini berdasarkan pada tujuan penelitian yang ingin dicapai. Karakteristik partisipan yang dipilih untuk dapat menggambarkan tujuan penelitian adalah: 1) partisipan adalah seorang wanita dengan orientasi seksual pada sesama jenis, 2) merupakan warga Indonesia yang berdomisili di Surabaya, 3) telah mencapai usia dewasa awal, yakni diatas 21 tahun, 4) memiliki tingkat religiusitas yang tinggi. Penentuan religiusitas pada partisipan penelitian melalui pengukuran menggunakan skala religiusitas yang dibagikan sebelum melakukan penelitian.

\section{Pengumpulan Data}

Cara yang digunakan peneliti dalam mengumpulkan informasi terkait topik penelitian ini adalah dengan metode wawancara mendalam. Moleong (2010, p.186) menyebutkan bahwa wawancara merupakan sebuah percakapan dengan tujuan tertentu yang dilakukan dua pihak yaitu orang yang akan memberikan pertanyaan dalam wawancara (interviewer) dan orang yang akan menjawab pertanyaan-pertanyaan tersebut (interviewee). Teknik wawancara yang digunakan adalah wawnacara semi terstruktur yang melibatkan pedoman umum berisikan garis besar pokok inti pertanyaan, yang dalam pelaksanaannya dapat dimodifikasi tergantung pada situasi dan kecukupan informasi yang telah diperoleh (Kusuma, 2016).

\section{Analisis Data}

Peneliti melakukan analisis pada data yang telah terkumpul menggunakan model Interpretative Phenomenological Analysis (IPA). Pendekatan dengan metode IPA memiliki sifat ganda. Pertama adalah bagi partisipan pribadi yaitu bagaimana partisipan akan memaknai pengalaman hidupnya. Kedua adalah bagi peneliti sendiri, yaitu ketika peneliti dapat memaknai pula pengalaman partisipan (Smith, Flower \& Larkin dalam Kahija \& Yudha, 2015, p.11). Pendekatan menggunakan metode IPA memiliki tujuan untuk dapat menelusuri apa yang dimaknai partisipan mengenai kehidupan pribadi serta sosialnya, karena kedua hal tersebut akan menjadi interaksi yang terjadi dalam diri partisipan, yang akan berguna pula bagi interpretasi penelitian (Smith, Flower \& Larkin dalam Kahija \& Yudha, 2015, p.11). Hubungan dialektis antara dua sisi kehidupan partisipan, baik kehidupan personal maupun sosial membentuk sebuah pola pemahaman yang dikembangkan oleh partisipan sendiri, sehingga partisipan mampu mendapatkan pemaknaan dari padanya (Kahija \& Yudha, 2015, p. 11). Analisis fenomenologi berdasarkan metode IPA dilakukan dalam beberapa tahap (Smith dalam Hajaroh, 2010), yaitu : (1) Membaca transkrip berulang-ulang (reading and re-reading), (2) Pencatatan awal (initial noting), (3) Mengambangkan tema yang muncul (developing emergent themes), (4) Mencari hubungan dari tema yang muncul (searching for connection across emergent themes), (5) Mendiskripsikan tema pokok atau tema induk (looking for patterns across cases).

\section{Keabsahan Data}

Pemerikasaan keabsahan data dalam penelitian kualitatif dapat menggunakan berbagi cara, salah satunya adalah melalui pemeriksaan sejawat melalui diskusi (member checking) (Moleong, 2010, p. 327-345). Member checking dilakukan dengan memaparkan hasil penelitian yang diperoleh baik hasil sementara maupun hasil akhir pada rekan sejawat dengan bentuk berupa diskusi (Moleong, 
2010, p.332). Tujuan dari diadakannya member checking adalah agar peneliti tetap bersikap jujur dan terbuka serta menjadi kesempatan untuk dapat melakukan pengujian awal terhadap hipotesis dari pemikiran peneliti (Moleong, 2010, p.333). Rekan sejawat yang dipilih untuk melakukan pengecekan terhadap hasil penelitian adalah rekan yang mampu secara pengetahuan dan pengalaman menguasai bidang yang akan diteliti atau mengikuti proses penelitian sampai pada mendapatkan informasi (Moleong, 2010).

\section{HAS IL D A N PEMBAHASAN}

Proses pengambilan keputusan pada individu dengan karakteristik religius dapat dilihat dari bagaimana proses tahapan pengambilan keputusan yang dilalui individu dan bagaimana karakteristik religius memberi pertimbangan dalam proses tahapan pengambilan keputusan tersebut.

\section{Proses Pengambilan Keputusan}

Menurut Janis dan Mann (1977), proses pengambilan keputusan pada individu dilakukan melalui lima tahapan, yaitu (1) Menilai tantangan (2) Survei Alternatif, (3) Mempertimbangkan alternatif, (4) Menyatakan Komitmen, dan (5) Bertahan melalui feedback negatif.

Proses pengambilan keputusan menunjukkan bahwa individu telah melalui semua tahapan sebelum akhirnya mengambil keputusan untuk menjadi seorang lesbian. Partisipan mendeskripsikan dirinya sebagai seseorang yang pada awalnya tidak menyadari bahwa ia adalah homoseksual. Pada masa SMP, ia masih menjalin hubungan dengan lawan jenis meskipun, ia sudah merasakan perasaan berbeda dengan perempuan. Hanya saja, ia tidak mengartikan perasaan tersebut lebih jauh. Saat ia digosipkan sebagai seorang lesbian, dan ia menyukai sahabatnya, ia merasa marah dan tersinggung karena merasa lesbian bukan orientasi seksualnya.

Menginjak masa SMA, ia menjalin pertemanan dengan seorang perempuan yang terpaut usia 9 tahun dengannya. Ia masih belum menyadari orientasi seksualnya sampai akhirnya ia tidak sengaja dicium oleh teman perempuannya. Respon awal yang dikeluarkan adalah ia merasa senang. Hal inilah yang membuat ia mempertanyakan kembali orientasi seksualnya. Saat ini, ia sedang menilai informasi terkait perasaannya. Ia merasakan konflik sementara dan mulai ragu apakah ia adalah seorang straight atau lesbian.

Sebelum ia memutuskan pacaran dengan teman perempuannya, ia mengalami perasaan bimbang. Hal yang ia lakukan adalah menghindar. Selama menghindar, ia mencoba berpikir dan menimbang apa yang sebenarnya ia rasakan. Ia mencari alternatif jawaban atas orientasi seksualnya. Ia menyadari bahwa ia memiliki perasaan suka dengan sesama jenis, tetapi ia merasa hal ini bukan hal yang tepat untuk dilakukan karena hal itu melanggar norma agama. Ia masih mengalami kebingungan sampai akhirnya berbicara dengan teman perempuannya tentang perasaannya dan orientasi seksualnya. Kemudian, teman perempuannya meyakinkan partisipan bahwa mereka memiliki perasaan suka yang sama. Teman perempuannya meyakinkan ia bahwa hal ini benar dilakukan karena mereka saling menyukai. Satu bulan setelahnya, mereka memutuskan untuk berpacaran.

Memutuskan untuk berpacaran dapat diartikan bahwa partisipan telah mengambil keputusan menjadi seorang lesbian dan berkomitmen menjalankan kehidupan menjadi seorang lesbian. Tantangan selanjutnya yang dihadapi adalah partisipan menghadapi timbal balik negatif dari lingkungan terkait orientasi seksualnya. Di Indonesia, LGBT tidak dianggap wajar karena bertentangan dengan norma agama yang berlaku di masyarakat.

INSAN Jurnal Psikologi dan Kesehatan Mental 2019, Vol. 4(1), 43-53

doi: 10.20473/jpkm.v4i12019.43-53 
Selama berpacaran, lingkungan sekitar tidak menaruh curiga kepada mereka karena menganggap hubungan mereka kakak dan adik. Ketika keluarga akhirnya mengetahui hubungan partisipan dan teman perempuannya, mereka menyatakan penolakan terhadap hubungan tersebut. Penolakan terberat datang dari ibu dan meminta partisipan untuk mengakhiri hubungannya. Partisipan mengiyakan saja dan berbohong ketika memiliki pasangan agar tidak terjadi konflik dengan keluarga.

Hingga saat ini, partisipan menghadapi berbagai macam timbal balik dari lingkungannya. Saudara partisipan ada yang memberikan dukungan dan ada juga saudara yang secara tegas menyatakan penolakan. Lingkungan teman-teman partisipan cenderung menguatkan keputusan partisipan untuk memilih jalan menjadi seorang lesbian. Lingkungan di luar itu dirasa acuh karena tidak langsung dengan jelas menegur dan "mendisiplinkan" partisipan tentang penyimpangan yang dilakukannya, yang mana menjadikan partisipan memiliki ketahanan akan umpan balik yang negatif.

\section{Religiusitas}

Glock dan Stark (1968) menjelaskan lima dimensi religiusitas; dimensi intelektual, dimensi ideologi, dimensi ritualistik, dimensi perasaan, dan konsekuensial. Gambaran religiusitas pada diri partisipan adalah masih mempercayai adanya Tuhan, dan ia membawa Tuhan di segala aspek kehidupannya. Pandangan terkait agama oleh Glock dimasukkan dalam dimensi intelektual. Pemahaman religiusitas pada partisipan mencakup pengetahuan tentang ajaran agama islam, ekspektasi sosial pada individu yang religius melakukan 6 rukun iman, menunaikan 5 rukun islam, pengalaman partisipan melakukan komunikasi dengan Tuhan, dan menjauhi larangannya. Dengan memiliki pengetahuan, partisipan kemudian mewujudkannya dalam bentuk kepercayaan terhadap ajaran agama. Menurut Glock, hal ini termasuk dalam dimensi ideologi. Kepercayaanny ditunjukkan melalui mempercayai Tuhan itu ada dan mempercayai sifat-sifatNya.

Di sisi lain, ia jarang melakukan ritual peribadatan. Alasan pertama adalah karena ia merasa berkomunikasi dengan Tuhan tidak hanya melalui sebatas praktik ritualistik, tetapi bersifat personal. Menurut Glock, hal ini termasuk dalam dimensi ritualistik. Partisipan berpendapat bahwa konstruksi agama terkesan membatasi komunikasinya dengan Sang Pencipta. Ia jarang melakukan kegiatan ritualistik keagamaan karena ia berpendapat berkomunikasi dengan Tuhan tidak hanya sebatas dengan ibadah salat dan berpuasa. Ia merasa dapat berkomunikasi dengan Tuhan dan merasakan adanya Tuhan tanpa harus melakukan ritual keagamaan. Walaupun seperti itu, ketika partisipan merasa terpuruk yang kemudian ia melakukan ibadah salat, ia terkadang merasa lebih baik. Menurut Glock, hal ini termasuk dimensi perasaan.

Selanjutnya, partisipan masih melakukan ibadah puasa ramadan karena menganggap kesakralan bulan Ramadan dan hari raya Idul Fitri. Menurut Glock, ini termasuk dalam dimensi konsekuensial. Menurut partisipan, terdapat alasan lain mengapa hingga saat ini ia masih merasakan perasaan bersalah ketika menjalankan ibadah. Ia merasa Tuhan tidak akan menerima ibadahnya karena ia merasa akan mengulangi perbuatannya. Partisipan belum menemukan kesimpulan terkait hal ini karena ia percaya bahwa Tuhan dan Agama adalah hal yang memiliki pemaknaan berbeda. Di sisi lain, ia merasa bahagia dengan menjadi lesbian, tetapi ia juga ingin menjadi muslim yang seutuhnya.

\section{SIMPULA N DAN SARAN}

Berdasarkan hasil penelitian, diketahui bahwa individu LGBT dengan karakteristik religius mengambil keputusan menjadi lesbian melalui tahapan pengambilan keputusan yaitu menilai tantangan, melakukan survei alternatif, mempertimbangkan alternatif, menyatakan komitmen, bertahan terhadap feedback negative. Faktor yang berperan dalam pengambilan keputusan terdiri dari internal dan eksternal. Pada faktor eksternal terdiri atas dukungan sosial meliputi dukungan 
dari pasangan, dukungan dari teman dekat, dukungan dari keluarga dan juga ketiadaan penolakan secara langsung dari lingkungan sekitar. Sementara faktor internal religiusitas partisipan memberi pertimbangan terkait pengambilan keputusan. Dimensi religiusitas yang dimiliki partisipan yaitu dimensi intelektual, ideologi, ritualistik, perasaan, dan konsekuensial. Beberapa dimensi religiusitas pada partisipan terlihat sangat menonjol dibandingkan dengan dimensi ritualistik yang cenderung rendah karena partisipan jarang melakukan ibadah wajib dan sunah.

Dengan pertimbangan adanya harapan dari partisipan untuk kembali menjadi heteroseksual, maka dapat disarankan bahwa sebaiknya partisipan dapat bersungguh-sungguh dalam mencapai harapannya. Salah satunya dengan cara meningkatkan dimensi ritualistik, yaitu dengan menunaikan ibadah wajib dan sunah. Setelah menjalankan dimensi ritualistik, partisipan diharapkan mampu untuk bertekad menjauhi laranganNya seperti menjauhi rekan-rekan LGBT dan mencari teman yang mampu mengajak mendekat kepadaNya. Luaran yang diharapkan dari tingginya dimensi religiusitas yang tinggi, yang didapat setelah partisipan meningkatkan dimensi ritualistiknya, adalah kembalinya orientasi seksual partisipan menjadi heteroseksual.

\section{DEKLARAS I POTENSI TERJADINYA KONFLIK KEPENTINGAN}

Helsa Evania Prastowo, Nastiti Dwicahyani, Gitajiwa Sekarnusa Ganies, Putri Anindita Vinasthika, \& Nafia Kusuma Indrayati tidak bekerja, menjadi konsultan, memiliki saham, atau menerima dana dari perusahaan atau organisasi manapun yang mungkin akan mengambil untung dari diterbitkannya naskah ini.

\section{PUSTAKA ACUAN}

Chaplin, J. P., \& Kartono, K. (1989). Kamus Lengkap Psikologi. Jakarta: Rajawali Pers.

Demartoto, A. (2013, June 4). Seks, Gender, Seksualitas Gay dan Lesbian. Diakses melalui https://argyo.staff.uns.ac.id/2013/04/24/seks-gender-seksualitas-gay-dan-lesbian/

Ermayani, T. (2017). LGBT Dalam Perspektif Islam. HUMANIKA, 17(2), 147-168. https://doi.org/10.21831/hum.v17i1.18569

Glock, C. Y., \& Stark, R. (1965). Religion and Society in Tension. Berkeley: Rand Mc Nally \& Company.

Herdiansyah, H. (2014). Metodologi Penelitian Kualitatif Untuk Ilmu Psikologi. Jakarta: Salemba Humanika.

Janis, I. L., \& Mann, L. (1979). Decision Making: A Psychological Analysis of Conflict, Choice, and Commitment. New York: Free Press.

Kaplan, H. \& Sadock, J.B. (1997). Sinopsis Psikiatri Ilmu Pengetahuan Perilaku Psikiatri Klinis (Terjemahan). Wiguna (ed). Jakarta: Universitas Trisakti

Moleong, L.J. (2010). Metodologi Penelitian Kualitatif. Bandung: PT Remaja Rosdakarya.

Muiz, A. (2017). Lesbi Akademik Potret Religiusitas Mahasiswi Perguruan Tinggi Islam. RELIGIA, 20(1), 71. https://doi.org/10.28918/religia.v20i1.679

Parlindungan, R., \& Roza Brilianty, A. (2014). Gambaran Religiusitas Pada Gay. Jurnal RAP, 5(1), 92102. Retrieved from http://ejournal.unp.ac.id/index.php/psikologi/article/view/6644

Subandi, M. A. (2013). Psikologi agama dan kesehatan mental. Yogyakarta: Unit Publikasi Fakultas Psikologi UGM 
Thouless, R. H. (2000). Pengantar psikologi agama. (Terjemahan: Machnun Husein). Jakarta: PT. Raja Grafindo Persada

Undang-Undang Dasar RI 1945.

Undang-Undang RI Nomor 12 Tahun 2005 tentang Pengesahan International Covenant on Civil and Political Rights (Kovenan Internasional tentang Hak-hak Sipil dan Politik).

Undang-Undang RI Nomor 39 Tahun 1999 tentang Hak Asasi Manusia.

Wulansari, D. (2015, Januari 15). Studi Kasus Mengenai Dinamika Dimensi Religiusitas Lesbian Muslim di Bandung. Diakes dari Maranatha Repository System: http://repository.maranatha.edu/8800/ 